\title{
Piperacillin-Tazobactam (TZP)
} Resistance in Escherichia coli Due to Hyperproduction of TEM-1 $\beta$-Lactamase Mediated by the Promoter $\mathbf{P a} / \mathbf{P b}$

\author{
Kaixin Zhou', Ying Tao', Lizhong Han, Yuxing Ni and Jingyong Sun* \\ Department of Clinical Microbiology, Ruijin Hospital, Shanghai Jiao Tong University School of Medicine, Shanghai, China
}

OPEN ACCESS

Edited by:

José Luis Capelo,

Faculdade de Ciências e Tecnologia da Universidade Nova de Lisboa,

Portugal

Reviewed by:

Jason Sahl,

Northern Arizona University,

United States

Abdelaziz Touati,

University of Béjaïa, Algeria

Yvonne Pfeifer,

Robert Koch Institute, Germany

*Correspondence: Jingyong Sun

13671578899@126.com

†These authors have contributed equally to this work

Specialty section:

This article was submitted to Antimicrobials, Resistance

and Chemotherapy,

a section of the journa

Frontiers in Microbiology

Received: 21 November 2018 Accepted: 01 April 2019

Published: 16 April 2019

Citation:

Zhou K, Tao Y, Han L, Ni Y and Sun J (2019) Piperacillin-Tazobactam (TZP) Resistance in Escherichia coli Due to Hyperproduction of TEM-1 $\beta$-Lactamase Mediated by the Promoter Pa/Pb.

Front. Microbiol. 10:833. doi: 10.3389/fmicb.2019.00833
TEM-1, mediated by plasmid and transposon, is the most commonly encountered $\beta$-lactamase in Gram-negative bacteria. Four different promoters upstream of blaTEMrelated genes have been identified: the weak $P 3$ promoter, and the strong promoters $\mathrm{Pa} / \mathrm{Pb}, \mathrm{P} 4$, and $P 5$. In this study, we investigated the genetic basis of a clinical strain of Escherichia coli (RJ904), which was found to be resistant to BLBLIs ( $\beta$-lactam/ $\beta$-lactamase inhibitors), including amoxicillin-clavulanate, ticarcillinclavulanate (TCC), and piperacillin-tazobactam (TZP) but sensitive to third-generation cephalosporins. The conjugation test and S1-nuclease pulsed-field gel electrophoresis (S1-PFGE) demonstrated that transfer of this resistance was mediated by a ca. $100 \mathrm{~kb}$ plasmid. The transformant with TZP resistance was screened out with the shortgun cloning. Sequence analysis revealed that the recombinant plasmid contained a blaTEM-1b gene with the strong promoter $\mathrm{Pa} / \mathrm{Pb}$. Different plasmids were cloned based on the clone vector PACYC184 with the insertion of the blaTEM-1b gene with promoters $\mathrm{Pa} / \mathrm{Pb}$ or $\mathrm{P} 3$. Susceptibility to TZP was determined by the $E$-test, agar dilution, and broth microdilution. The level of bla TEM-1b-specific transcription was determined by quantitative real-time PCR. Substitution of $\mathrm{Pa} / \mathrm{Pb}$ for $\mathrm{P} 3$ resulted in a 128-fold decline of the MIC value of TZP, from $>1024 \mathrm{mg} / \mathrm{L}$ to $8 \mathrm{mg} / \mathrm{L}$, and a significantly lower blaTEM-1b expression level. Hyperproduction of TEM-1 $\beta$-lactamase mediated by the promoter $\mathrm{Pa} / \mathrm{Pb}$ was responsible for high resistance to TZP in E. coli. Our data show possible risks of resistance development in association with the clinical use of TZP. The blaTEM promoter modifications should be considered for whole genome whole-genome sequencing-inferred bacterial antimicrobial susceptibility testing.

Keywords: TZP resistance, Escherichia coli, $\mathrm{Pa} / \mathrm{Pb}, \beta$-lactamase, antimicobial

\section{INTRODUCTION}

The production of $\beta$-lactamases is the predominant cause of resistance to $\beta$-lactam antibiotics in Gram-negative bacteria (Bonnet, 2004), including the hyperproduction of plasmid-mediated TEM$1 \beta$-lactamases, production of extended-spectrum beta-lactamases (ESBLs), plasmid-mediated AmpC enzymes (Caroff et al., 1999) and carbapenem-hydrolyzing $\beta$-lactamases (carbapenemases) 
(Wu et al., 1994; Jacoby and Munoz-Price, 2005). Combining $\beta$-lactam and a $\beta$-lactamase inhibitor (BLBLIs) was a common strategy to overcome resistance (Chaibi et al., 1999; PerezLlarena and Bou, 2009). However, resistance to BLBLIs has also been regularly observed (Pérez-Moreno et al., 2010; Waltner-Toews et al., 2011).

TEM-1 was described in the early 1960s as the first plasmidmediated $\beta$-lactamase in Gram-negative bacteria (Datta and Kontomichalou, 1965). Being plasmid and transposon-mediated has facilitated its spread to other species of bacteria and it is now the most commonly encountered $\beta$-lactamase in Gramnegative bacteria (Bradford, 2001). The subgroups were defined and designated $\mathrm{a}, \mathrm{b}$, and $\mathrm{c}$ for a given bla TEM gene derivative, because of their relation to a certain number of nucleotide differences in their structural gene sequence (Leflon-Guibout et al., 2000). The corresponding bla $a_{\mathrm{TEM}-1 \mathrm{~b}}$ gene derives from bla $a_{\mathrm{TEM}-1 \mathrm{a}}$ by three base pair changes: C226T, C436T, and G604T, silent base pair change. bla $a_{\mathrm{TEM}-1 \mathrm{c}}$ gene differs from bla $a_{\mathrm{TEM}-1 \mathrm{a}}$ by the nucleotide substitution C436T, which is also silent. bla $a_{\mathrm{TEM}-2}$ differs from bla $a_{\mathrm{TEM}-1 \mathrm{a}}$ at position 317 , where a A-to-C substitution leads to Gln39Lys (Goussard and Goussard, 1991). Previous studies identified four bla $a_{\text {TEM }}$ promoters: the weak $P 3$ promoter, and the strong promoters $P a / P b, P 4$, and P5 (Lartigue et al., 2002). P3 corresponds to the promoter of the bla $a_{\text {TEM }}$ gene located in a Tn2 or Tn 3 transposon (Sutcliffe, 1978; Lartigue et al., 2002; Partridge and Hall, 2005). A singlebase pair mutation $(\mathrm{C} 32 \mathrm{~T})$ results in the stronger overlapping promoters $\mathrm{Pa} / \mathrm{Pb}$, first found upstream of the gene $b l a_{\mathrm{TEM}-2}$, and produces larger amounts of the enzyme compared with the promoter P3 (Chen and Clowes, 1987a,b). Thus, an updated bla $a_{\text {TEM }}$ gene nomenclature was proposed on the basis of the sequences of structural bla $a_{\mathrm{TEM}}$ genes and their promoters (Goussard and Courvalin, 1999).

Lartigue et al. (2002) assessed and compared the respective impact of the four promoters on $\beta$-lactam resistance. Among the recombinant plasmids, one with a $b l a_{\mathrm{TEM}-1 \mathrm{~b}}$ gene driven by a $\mathrm{Pa} / \mathrm{Pb}$ promoter resulted in resistance to AMC and ticarcillin-clavulanate (TCC), but susceptibility to piperacillintazobactam (TZP) with a MIC value of $2 \mathrm{mg} / \mathrm{L}$. In this study, the mechanism of TZP resistance was investigated in Escherichia coli RJ904, a clinical isolate containing the bla $a_{\mathrm{TEM}-1 \mathrm{~b}}$ gene with a $\mathrm{Pa} / \mathrm{Pb}$ promoter. Experimental and genomic data support a role for $\mathrm{Pa} / \mathrm{Pb}$ promoter regulation, leading to $b l a_{\mathrm{TEM}-1 \mathrm{~b}}$ hyperproduction, as the primary basis for TZP resistance in this isolate.

\section{MATERIALS AND METHODS}

\section{Ethics Statement}

This study was approved by the ethics committee of Ruijin Hospital, School of Medicine, Shanghai Jiao Tong University, Shanghai, China and the Review Board exempted the requirement for written informed consent because this retrospective study only focused on bacteria and did not affect the patients.

\section{Bacterial Strains and Growth Condition}

The clinical strain E. coli RJ904 was obtained from the blood specimen of a hospitalized patient in Shanghai, China (Ruijin Hospital, School of Medicine, Shanghai Jiao Tong University) in 2005. Ceftazidime was used for the medication. The patient's condition improved after the treatment and the patient was discharged. The isolate was identified using VITEK2 automated systems (BioMérieux, France). All of the plasmids used in this study are listed in Supplementary Table S1. All cloning procedures were carried out in E. coli $(\mathrm{DH} 5 \alpha)$, and antibiotics were used with suitable concentrations for plasmid selection when necessary. All the E. coli strains were routinely grown in Luria-Bertani (LB) broth (Oxoid) and incubated overnight at $35^{\circ} \mathrm{C}$.

\section{Antimicrobial Susceptibility Testing}

Susceptibility testing of all the antibiotics for the clinical strain RJ904, transconjugant RJ904C, and recombinant vectors RJ904-PA/PB was determined using the E-test (bioMérieux, France). The antibiotic susceptibility of the strains to piperacillin with a fixed concentration of tazobactam (TZP, $4 \mathrm{mg} / \mathrm{L}$ ) was determined using three methods: E-test, agar dilution, and broth microdilution method. The results were interpreted based on the guidelines of the CLSI (2014).

\section{Conjugal Transfer Experiments and S1-Nuclease Pulsed-Field Gel Electrophoresis (S1-PFGE)}

Conjugal transfer experiments were performed in broth culture using the strain RJ904 as the donor and the sodium azideresistant strain E. coli $\mathrm{J}_{53 \mathrm{Azi}^{\mathrm{r}}}$ as the recipient. Selection was performed with piperacillin $(100 \mathrm{mg} / \mathrm{L})$, tazobactam $(4 \mathrm{mg} / \mathrm{L})$, and sodium azide $(100 \mathrm{mg} / \mathrm{L})$. The plasmid DNA of RJ904 and its transconjugant RJ904C was examined using S1-PFGE as previously described (Barton et al., 1995).

\section{Plasmid Construction}

The principle features of all plasmids are listed in Supplementary Table S1.

First, the fragment of $b l a_{\mathrm{TEM}-1 \mathrm{~b}}$ gene was screened by the shortgun cloning. In brief, plasmid DNAs of pRJ904 were extracted with the Plasmid DNA Mini Kit (Omega). pRJ904 and the clone vector pACYC184 were digested with restriction enzymes BamHI and HindIII (Thermo Fisher Scientific) and ligated to construct a DNA library, which was used to transform the competent cells. Selection was then performed with piperacillin $(100 \mathrm{mg} / \mathrm{L})$, tazobactam $(4 \mathrm{mg} / \mathrm{L})$, and chloramphenicol $(50 \mathrm{mg} / \mathrm{L})$. The new cloned plasmid was named pRJ904-PA/PB.

The recombinant vector was cloned as described by Lartigue et al. (2002) using the same primers (BamHI-P-F and BamHI-P-R), clone vector, and restriction enzyme digestion site. pRJ904-PA/PB and p749 (MH491004) served as templates, respectively. p749 was a plasmid from E. coli retained by our laboratory that contained the $b l a_{\mathrm{TEM}-1 \mathrm{~b}}$ gene and promoter region with $99 \%$ base pair identity to pRJ904, except a point 
mutation $(\mathrm{T} 32 \mathrm{C})$ in the promoter region of $b l a_{\mathrm{TEM}-1 \mathrm{~b}}$, resulting in substitution of the promoter $\mathrm{Pa} / \mathrm{Pb}$ for $\mathrm{P} 3$. The PCR products were purified and digested with $\mathrm{BamHI}$ (Thermo Fisher Scientific) and cloned into pACYC184 to construct plasmids pRJ904-PA/PB-P and pRJ904-P3-P. Both plasmids were cloned based on pACYC184, and the bla $a_{\mathrm{TEM}-1 \mathrm{~b}}$ gene was inserted; however, pRJ904-PA/PB-P contained the $\mathrm{Pa} / \mathrm{Pb}$ promoter while pRJ904-P3-P contained the $P 3$ promoter.

After cloning, all of the plasmids were transformed into E. coli $\mathrm{DH} 5 \alpha$ cells by using standard techniques (Denman, 1983). Selection was performed on an LB agar plate containing ampicillin (100 $\mathrm{mg} / \mathrm{L})$ and chloramphenicol (50 $\mathrm{mg} / \mathrm{L})$. Proper integration of all the constructs were verified by PCR amplification with the primers $184-\mathrm{F}$ and $184-\mathrm{R}$ binding on pACYC184, followed by sequencing of the PCR product. The direction of the $b l a_{\mathrm{TEM}-1 \mathrm{~b}}$ fragments in all the constructs were opposite to the tetR gene of pACYC184 in order to rule out the possible expression of the tet $R$ gene.

\section{Transcriptional Analysis of bla TEM $-1 b$}

For real-time PCR, the indicated E. coli strains were grown in LB broth and harvested at an OD600 of 1. The RNA was extracted using RNeasy Mini Kit (Qiagen), and then used to generate cDNA with PrimeScript ${ }^{\mathrm{TM}}$ RT Master Mix (TaKaRa). RT-PCR was performed using SYBR green PCR master mix (Applied Biosystems) with the primer pair TEM-F and TEM-R (Supplementary Table S2) on a cobas $\mathrm{z}_{480}{ }^{\circledR}$ system (Roche) (Her and Schutzbank, 2018). Amplification of the 16S rRNA gene (as an endogenous control) was performed to standardize the amount of sample RNA or DNA added to a reaction. Relative quantification was determined by the $2^{-\Delta \Delta C T}$ method. Each assay was performed in triplicate with three independent cultures. Statistical comparisons were performed by one-way analysis of variance (ANOVA) followed by Holm-Sidak tests to compare selected data pairs. Values of $P<0.05$ were considered statistically significant.

\section{Nucleotide Sequence Accession Number}

The nucleotide sequence containing a bla $a_{\mathrm{TEM}-1 \mathrm{~b}}$ gene with the promoter $\mathrm{Pa} / \mathrm{Pb}$ from the clinical strain RJ904 has been deposited in the GenBank sequence database under accession number MH357372.

\section{RESULTS}

\section{Plasmid-Mediated Transfer of the Resistance to $\beta$-Lactam and $\beta$-Lactamase Inhibitor Combinations}

The clinical isolate RJ904 was determined by E-test and found to be highly resistant to BLBLIs, including AMC, TCC, and TZP (MICs>256 mg/L), but was susceptible to third-generation (Table 1). Resistance to TZP was transferable using the broth mate conjugation assay. Although the transconjugant RJ904C showed a decreased MIC to third-generation cephalosporins, the MIC values of BLs and BLBLIs were all significantly higher
TABLE 1 | Antibiotic susceptibilities of E. coli strains RJ904, RJ904C, RJ904-PA/PB, RJ904-P3.

\begin{tabular}{lccccc}
\hline Antibiotics & \multicolumn{5}{c}{ MIC (mg/L) } \\
\cline { 2 - 6 } & J53 & DH5 $\boldsymbol{~}$ & RJ904 & RJ904C & RJ904-PA/PB \\
\hline Amoxicillin & 4 & 4 & $>256$ & $>256$ & $>256$ \\
Piperacillin & 2 & 2 & $>256$ & $>256$ & $>256$ \\
Amoxicillin-clavulanate & 4 & 2 & $>256$ & $>256$ & $>256$ \\
Ticarcillin-clavulanate & 2 & 1 & $>256$ & $>256$ & $>256$ \\
Piperacillin-tazobactam & 1 & 0.5 & $>256$ & $>256$ & $>256$ \\
Cefazolin & 4 & 4 & $>256$ & $>256$ & $>256$ \\
Cefuroxime & 4 & 4 & 32 & 4 & 8 \\
Cefoperazone & 0.125 & 0.064 & $>256$ & 32 & 256 \\
Cefotaxime & 0.032 & 0.032 & 0.5 & 0.064 & 0.25 \\
Ceftazidime & 0.125 & 0.125 & 2 & 0.5 & 2 \\
Cefoxitin & 4 & 4 & 64 & 4 & 4 \\
\hline
\end{tabular}

than that of the recipient strain E. coli J53Azir ${ }^{\mathrm{r}}$. The results of S1-PFGE confirmed the presence of a ca. $100 \mathrm{~kb}$ plasmid in both the donor strain RJ904 and the transconjugant RJ904C (Supplementary Figure S1).

\section{Hyperproduction of TEM-1b $\beta$-Lactamase Mediated by the Promoter $\mathrm{Pa} / \mathrm{Pb}$}

The shortgun cloning and sequence analysis revealed that the recombinant vector pRJ904-PA/PB contained a DNA insertion of approximately $3.9 \mathrm{~kb}$ containing the $b l a_{\mathrm{TEM}-1 \mathrm{~b}}$ gene, located on the resolvase gene $(\operatorname{tnpR})$ of $\mathrm{Tn} 2$, and the promoter upstream the $b l a_{\mathrm{TEM}-1 \mathrm{~b}}$ gene was $\mathrm{Pa} / \mathrm{Pb}$ (Figure 1). The MIC value of BLs and BLBLIs of E. coli RJ904-PA/PB was similar to that of the transconjugant RJ904C (Table 1).

The level of $b l a_{\mathrm{TEM}-1 \mathrm{~b}}$-specific transcription was determined by quantitative RT-PCR. As shown in Figure 2, RJ904-PA/PB demonstrated a significantly higher relative $b l a_{\mathrm{TEM}-1 \mathrm{~b}}$ expression level than RJ904-P3-P $(P<0.01)$.

\section{Expression of TEM-1b for pRJ904-PA/PB-P and pRJ904-P3-P}

To further confirm that the resistance to TZP is caused by the promoter $\mathrm{Pa} / \mathrm{Pb}$ and for comparison with the results of Lartigue et al. (2002), the plasmids pRJ904-PA/PB-P and pRJ904-P3-P were constructed.

The MIC value of TZP for all strains was determined by three different methods (Table 2). The MIC values of RJ904$\mathrm{PA} / \mathrm{PB}$ and RJ904-PA/PB-P were $>256 \mathrm{mg} / \mathrm{L}$ in the $E$-test and were $\geq 024 \mathrm{mg} / \mathrm{L}$ in agar dilution and broth microdilution tests, indicating no difference from the susceptibility profile of the original strain RJ904 and the transconjugant RJ904C. However, RJ904-P3-P demonstrated significantly declined MIC values of $8 \mathrm{mg} / \mathrm{L}$ (agar dilution and $E$-test) or $16 \mathrm{mg} / \mathrm{L}$ (broth microdilution test), and $4 \mathrm{mg} / \mathrm{L}$ (agar dilution and $E$-test) or $8 \mathrm{mg} / \mathrm{L}$ (broth microdilution test), respectively. Consistently, RJ904-PA/PB-P demonstrated a significantly higher $b l a_{\mathrm{TEM}-1 \mathrm{~b}}$ expression level than RJ904-P3-P. 


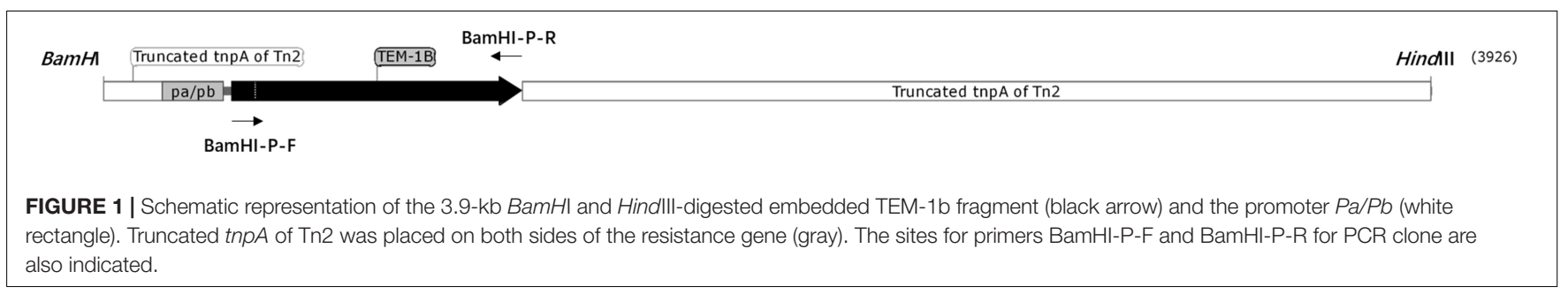

\section{DISCUSSION}

The conjugation experiment demonstrated that resistance to TZP can be transferred from RJ904 to J53 Azir ${ }^{\mathrm{r}}$. The short gun method was used to screen out a strain that was highly resistant to TZP, and sequence analysis revealed that the plasmid harbored a 3.9$\mathrm{kb}$ insertion embedded in the bla $a_{\mathrm{TEM}-1 \mathrm{~b}}$ gene with the strong promoter $\mathrm{Pa} / \mathrm{Pb}$. The mutant strain RJ904-P3-P with the weak promoter $P 3$ demonstrated substantially declining MIC values to TZP. Moreover, RJ904-PA/PB and RJ904-PA/PB-P demonstrated a higher bla $a_{\mathrm{TEM}-1 \mathrm{~b}}$ expression level than RJ904-P3-P. Altogether, these data provide strong functional evidence that the acquisition

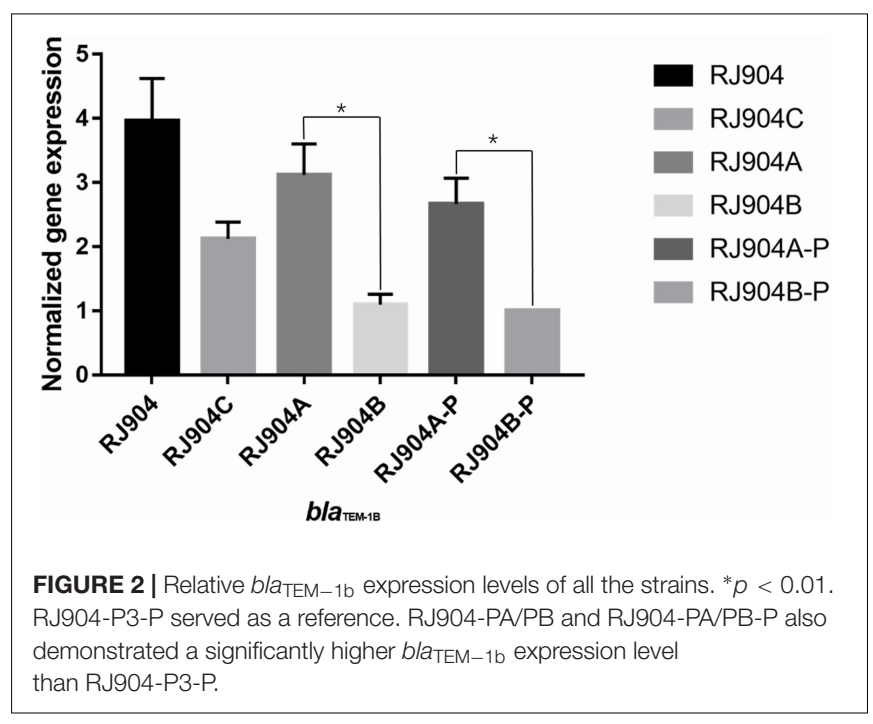

TABLE 2 | Susceptibility testing results of $E$. coli strains to piperacillin with $4 \mathrm{mg} / \mathrm{L}$ of tazobactam (TZP).

\begin{tabular}{lccr}
\hline Strain & E-test (mg/L) & $\begin{array}{c}\text { Agar dilution } \\
(\mathbf{m g} / \mathbf{L})\end{array}$ & $\begin{array}{c}\text { Broth } \\
\text { microdilution } \\
\text { (mg/L) }\end{array}$ \\
\hline ATCC25922 & 2 & 2 & 1 \\
J53 & 1 & 1 & 1 \\
DH5 & 0.5 & 1 & 2 \\
RJ904 & 256 & $\geq 1024$ & $\geq 1024$ \\
RJ904C & 256 & $\geq 1024$ & $\geq 1024$ \\
RJ904-PA/PB & $>256$ & $\geq 1024$ & $\geq 1024$ \\
RJ904-PA/PB-P & $>256$ & $\geq 1024$ & $\geq 1024$ \\
RJ904-P3-P & 4 & 4 & 8 \\
\hline
\end{tabular}

aMIC breakpoint (mg/L): $S \leq 16 / 4 ;$ l: 32/4-64/4; $R \geq 128 / 4$ (CLSI). of TZP resistance was due to the hyperproduction of TEM-1b $\beta$-lactamases mediated by the strong promoter $\mathrm{Pa} / \mathrm{Pb}$.

Lartigue et al. (2002) suggested that the bla $a_{\mathrm{TEM}-1 \mathrm{~b}}$ gene with a $\mathrm{Pa} / \mathrm{Pb}$ promoter could contribute to the resistance to AMC and TCC but not to TZP with a MIC value of $2 \mathrm{mg} / \mathrm{L}$, suggesting the potential importance of this promoter for $\beta$-lactam resistance. However, we found that strain RJ904-PA/PB, which also contained the $b l a_{\mathrm{TEM}-1 \mathrm{~b}}$ gene with a $\mathrm{Pa} / \mathrm{Pb}$ promoter, was highly resistant to TZP with a MIC value $>256 \mathrm{mg} / \mathrm{L}$. To identify possible causes of the difference, we replicated the experiment of Lartigue et al. (2002) using the exact same primers, clone vector, and restriction enzyme digestion site to clone the plasmid with the $b l a_{\mathrm{TEM}-1 \mathrm{~b}}$ gene and $\mathrm{Pa} / \mathrm{Pb}$ promoter (pRJ904-PA/PB-P), which was compared to a plasmid with the P3 promoter (pRJ904-P3-P). We next determined the MIC value of TZP of all strains. Since several authors have claimed that the MIC determination of TZP can be method-dependent and strains exhibited discordant behavior and heterogeneous resistance in different methods (Creely et al., 2013; Shubert et al., 2014), we used three methods for susceptibility testing to avoid the methodological impact: broth microdilution, agar dilution, and E-test. Several studies have compared the results of TZP susceptibility testing with broth microdilution and agar dilution methods for isolates of various species,(Thomson et al., 2008; Creely et al., 2013; Steensels et al., 2013; Shubert et al., 2014) and broth microdilution showed a tendency toward higher MIC values than agar dilution (Steensels et al., 2013). In the present study, there was no difference in the MIC values of RJ904-PA/PB-P to those of strains RJ904, RJ904C, and $\mathrm{RJ} 904-\mathrm{PA} / \mathrm{PB}$ regardless of the method used. All these strains with a promoter $\mathrm{Pa} / \mathrm{Pb}$ demonstrated high resistance to TZP unlike Lartigue's transformants, while strains with a promoter P3 (RJ904-P3 and RJ904-P3-P) demonstrated a significantly declined MIC value ultimately becoming susceptible to TZP, which is consistent with the findings of Lartigue's transformants with a P3 promoter. E. coli $\mathrm{DH} 5 \alpha$ was used as the recipient rather than E. coli NM554. However, RJ904, the transconjugant RJ904C (E. coli J53), and RJ904-PA/PB-P (E. coli DH5 $\alpha$ ) all demonstrated high resistance to TZP. These results indicate that the recipient will not have a great impact on the expression of drug-resistant genes.

Nevertheless, when we repeated the experiment, we reached a different conclusion. The strains with promoter $\mathrm{Pa} / \mathrm{Pb}$ in our study demonstrated high resistance to TZP while Lartigue's transformants was susceptible to TZP. Although the reason for this discrepancy is not yet clear, our results from several independent assessments all indicate that the resistance to TZP 
was due to hyperproduction of TEM-1b $\beta$-lactamases mediated by the strong promoter $\mathrm{Pa} / \mathrm{Pb}$. However, overexpression of blaTEM-1 can lead to resistance, including clavulanate and sulbactam (Stapleton et al., 1995; Waltner-Toews et al., 2011). bla $a_{\text {TEM-1 }}$ hyperproduction resulting from an increase in bla $a_{\mathrm{TEM}-1}$ gene dosage has also been documented ( $\mathrm{Wu}$ et al., 1995; Waltner-Toews et al., 2011). Schechter et al. (2018) claimed that tandem bla $a_{\mathrm{TEM}-1}$ gene amplification, leading to bla $a_{\mathrm{TEM}-1}$ hyperproduction, as the primary basis for TZP resistance in E. coli. These results indicated that bla $a_{\mathrm{TEM}-1}$ hyperproduction can lead to BLBLIs resistance, including TZP.

Whole-genome sequencing (WGS) can help to infer antimicrobial susceptibility accurately using a single assay (Ellington et al., 2017). However, most existing databases focus only on the commonly known resistance loci while neglecting the role of promoters. Our finding should be considered for the acquisition of more accurate WGS-inferred bacterial antimicrobial susceptibility testing. Importantly, these data add to the growing body of evidence that the same resistance gene with different promoters will result in completely different susceptibility testing results. Thus, when performing WGS-inferred AST, we should not only assess the resistance genes but should also analyze their promoter sequences

\section{REFERENCES}

Barton, B. M., Harding, G. P., and Zuccarelli, A. J. (1995). A general method for detecting and sizing large plasmids. Anal. Biochem. 226, 235-240. doi: 10.1006/ abio. 1995.1220

Bonnet, R. (2004). Growing group of extended-spectrum beta-lactamases: the CTX-M enzymes. Antimicrob. Agents Chemother. 48, 1-14. doi: 10.1128/AAC. 48.1.1-14.2004

Bradford, P. A. (2001). Extended-spectrum beta-lactamases in the 21st century: characterization, epidemiology, and detection of this important resistance threat. Clin. Microbiol. Rev. 14, 933-951. doi: 10.1128/CMR.14.4.933-951.2001

Caroff, N., Espaze, E., Berard, I., Richet, H., and Reynaud, A. (1999). Mutations in the ampC promoter of Escherichia coli isolates resistant to oxyiminocephalosporins without extended spectrum beta-lactamase production. FEMS Microbiol. Lett. 173, 459-465.

Chaibi, E. B., Sirot, D., Paul, G., and Labia, R. (1999). Inhibitor-resistant TEM betalactamases: phenotypic, genetic and biochemical characteristics. J. Antimicrob. Chemother. 43, 447-458. doi: 10.1093/jac/43.4.447

Chen, S. T., and Clowes, R. C. (1987a). Nucleotide sequence comparisons of plasmids pHD131, pJB1, pFA3, and pFA7 and beta-lactamase expression in Escherichia coli, Haemophilus influenzae, and Neisseria gonorrhoeae. J. Bacteriol. 169, 3124-3130.

Chen, S. T., and Clowes, R. C. (1987b). Variations between the nucleotide sequences of Tn1, Tn2, and Tn3 and expression of beta-lactamase in Pseudomonas aeruginosa and Escherichia coli. J. Bacteriol. 169, 913-916.

CLSI (2014). Clinical and Laboratory Standards Institutes. Performance Standards for Antimicrobial Susceptibility Testing; 24th Informational Supplement, M100S24. Wayne,PA: CLSI.

Creely, D., Zambardi, G., van Belkum, A., Dunne, W. M., Peyret, M., Gayral, J. P., et al. (2013). International dissemination of Escherichia coli strains with discrepant behaviour in phenotypic antimicrobial susceptibility tests. Eur. J. Clin. Microbiol. Infect. Dis. 32, 997-1002. doi: 10.1007/s10096-013-1837-5

Datta, N., and Kontomichalou, P. (1965). Penicillinase synthesis controlled by infectious R factors in Enterobacteriaceae. Nature 208, 239-241. doi: 10.1038/ 208239a0

Denman, A. M. (1983). Molecular cloning: a laboratory manual. Immunology 49:411. simultaneously. Our finding also shed light on the possibility of a fast identification using a simple PCR and sequencing to identify strong promoters and weak promoters and to infer antimicrobial susceptibility.

\section{AUTHOR CONTRIBUTIONS}

All authors listed have made a substantial, direct and intellectual contribution to the work, and approved it for publication.

\section{FUNDING}

This work was funded by the Medical-engineering cross project of Shanghai Jiao Tong University (No. YG2015MS59).

\section{SUPPLEMENTARY MATERIAL}

The Supplementary Material for this article can be found online at: https://www.frontiersin.org/articles/10.3389/fmicb. 2019.00833/full\#supplementary-material

Ellington, M. J., Ekelund, O., Aarestrup, F. M., Canton, R., Doumith, M., Giske, C., et al. (2017). The role of whole genome sequencing in antimicrobial susceptibility testing of bacteria: report from the EUCAST Subcommittee. Clin. Microbiol. Infect. 23, 2-22. doi: 10.1016/j.cmi.2016.11.012

Goussard, S., and Courvalin, P. (1999). Updated sequence information for TEM beta-lactamase genes. Antimicrob. Agents Chemother. 43, 367-370. doi: 10.1128/ AAC.43.2.367

Goussard, S., and Goussard, A. (1991). Sequences of the genes blaT-1B and blaT-2. Gene 102, 71-73. doi: 10.1016/0378-1119(91)90540-R

Her, T., and Schutzbank, T. E. (2018). Evaluation of the Luminex ARIES(R) system for the detection and quantification of BK virus (BKV) DNA in plasma samples from kidney transplant recipients. Diagn. Microbiol. Infect. Dis. doi: 10.1016/j. diagmicrobio.2018.12.004 [Epub ahead of print].

Jacoby, G. A., and Munoz-Price, L. S. (2005). The new beta-lactamases. N. Engl. J. Med. 352, 380-391. doi: 10.1056/NEJMra041359

Lartigue, M. F., Leflon-Guibout, V., Poirel, L., Nordmann, P., and NicolasChanoine, M. H. (2002). Promoters P3, Pa/Pb, P4, and P5 upstream from bla(TEM) genes and their relationship to beta-lactam resistance. Antimicrob. Agents Chemother. 46, 4035-4037. doi: 10.1128/AAC.46.12.4035-4037.2002

Leflon-Guibout, V., Heym, B., and Nicolas-Chanoine, M. (2000). Updated sequence information and proposed nomenclature for bla(TEM) genes and their promoters. Antimicrob. Agents Chemother. 44, 3232-3234. doi: 10.1128/ AAC.44.11.3232-3234.2000

Partridge, S. R., and Hall, R. M. (2005). Evolution of transposons containing blaTEM genes. Antimicrob. Agents Chemother. 49, 1267-1268. doi: 10.1128/ AAC.49.3.1267-1268.2005

Perez-Llarena, F. J., and Bou, G. (2009). Beta-lactamase inhibitors: the story so far. Curr. Med. Chem. 16, 3740-3765. doi: 10.2174/092986709789104957

Pérez-Moreno, M. O., Katargina, O., Pérez-Moreno, M., Carulla, M., Rubio, C., Jardí, A. M., et al. (2010). Mechanisms of reduced susceptibility to amoxycillinclavulanic acid in Escherichia coli strains from the health region of Tortosa (Catalonia, Spain). Clin. Microbiol. Infect. 10, 234-241. doi: 10.1111/j.1198743X.2004.00766.x

Schechter, L. M., Creely, D. P., Garner, C. D., Shortridge, D., Nguyen, H., Chen, L., et al. (2018). Extensive gene amplification as a mechanism for piperacillintazobactam resistance in Escherichia coli. Mbio 9:e00583-18. doi: 10.1128/mBio. 00583-18 
Shubert, C., Slaughter, J., Creely, D., van Belkum, A., Gayral, J. P., Dunne, W. M., et al. (2014). Population analysis of Escherichia coli isolates with discordant resistance levels by piperacillin-tazobactam broth microdilution and agar dilution testing. Antimicrob. Agents Chemother. 58, 1779-1781. doi: 10. 1128/AAC.02181-13

Stapleton, P., Wu, P. J., King, A., Shannon, K., French, G., and Phillips, I. (1995). Incidence and mechanisms of resistance to the combination of amoxicillin and clavulanic acid in Escherichia coli. Antimicrob. Agents Chemother. 39, 2478-2483. doi: 10.1128/AAC.39.11.2478

Steensels, D., Smeets, T., Zambardi, G., Goessens, W., Beenhouwer, H. D., and Verhaegen, J. (2013). "Evaluation of piperacillin-tazobactam susceptibility testing by 2 reference and 3 commercial methods in selected E. coli strains," in Proceedings of the 53rd ICAAC Congress, (Denver, CO).

Sutcliffe, J. G. (1978). Nucleotide sequence of the ampicillin resistance gene of Escherichia coli plasmid pBR322. Proc. Natl. Acad. Sci. U.S.A. 75, 3737-3741. doi: 10.1073/pnas.75.8.3737

Thomson, K. S., Black, J., Moland, E. S., Reuben, J., Wiles, T., and Brasso, W. (2008). Irreproducible piperacillin/tazobactam minimum inhibitory concentrations in microdilution tests with Escherichia coli strains. Int. J. Antimicrob. Agents 31, 83-85. doi: 10.1016/j.ijantimicag.2007.08.015

Waltner-Toews, R. I., Paterson, D. L., Qureshi, Z. A., Sidjabat, H. E., AdamsHaduch, J. M., Shutt, K. A., et al. (2011). Clinical characteristics of bloodstream infections due to ampicillin-sulbactam-resistant, non-extendedspectrum-beta-lactamase-producing Escherichia coli and the role of TEM-1 hyperproduction. Antimicrob. Agents Chemother. 55, 495-501. doi: 10.1128/ AAC.00797-10

Wu, P. J., Shannon, K., and Phillips, I. (1994). Effect of hyperproduction of TEM1 beta-lactamase on in vitro susceptibility of Escherichia coli to beta-lactam antibiotics. Antimicrob. Agents Chemother. 38, 494-498. doi: 10.1128/AAC.38. 3.494

Wu, P. J., Shannon, K., and Phillips, I. (1995). Mechanisms of hyperproduction of TEM-1 beta-lactamase by clinical isolates of Escherichia coli. J. Antimicrob. Chemother. 36, 927-939. doi: 10.1093/jac/36.6.927

Conflict of Interest Statement: The authors declare that the research was conducted in the absence of any commercial or financial relationships that could be construed as a potential conflict of interest.

Copyright (c) 2019 Zhou, Tao, Han, Ni and Sun. This is an open-access article distributed under the terms of the Creative Commons Attribution License (CC BY). The use, distribution or reproduction in other forums is permitted, provided the original author(s) and the copyright owner(s) are credited and that the original publication in this journal is cited, in accordance with accepted academic practice. No use, distribution or reproduction is permitted which does not comply with these terms. 